\title{
PENGARUH KUALITAS PRODUK, LOKASI DAN KUALITAS PELAYANAN TERHADAP KEPUTUSAN PEMBELIAN PADA RESTAURANT " $X$ "
}

\section{Zainiyatul Qoyum}

Fakultas Ekonomi dan Bisnis

Universitas Muhammadiyah Gresik

\section{ABSTRAK}

Tujuan dari penelitian ini adalah untuk menjelaskan pengaru dari kualitas produk, lokasi dan kualitas layanan terhadap keputusan pembelian pada restaurant cepat saji MCD GKB. Pengambilan sample menggunakan incidental sampling dimana semua orang yang bertemu dengan peneliti dapat diambil sebagai responden dengan jumlah sampel sebanyak 100 orang. Analisis data menggunakan regresi linear berganda. Hasil analisis menunjukkan bahwa ada pengaru yang signifikan secara parsial antara kualitas produk, lokasi dan kualitas layanan terhadap keputusan pembelian. Hasil diatas menginterpretasikan bahwa kualitas produk, lokasi dan kualitas layanan dapat meningkatkan keputusan pembelian pada restoran cepat saji MCD GKB

\section{Keywords : Kualitas Produk, Lokasi, Kualitas Layanan}

\section{PENDAHULUAN}

Di era globalisasi seperti saat ini perkembangan pemahaman konsumen terhadap kualitas produk barang dan jasa sudah cukup baik dan hampir merata di seluruh pelosok kota, seiring dengan kondisi tersebut dunia pemasaran secara otomatis akan di hadapkan pada persaingan yang sangat ketat. Dengan lingkungan yang padat persaingan ini, konsumen memiliki peluang yang luas untuk mendapatkan produk dengan sederet pilihan sesuai dengan keinginan dan kebutuhannya. Menurut Zwastha dan Irawan dalam Kasali (2001:24): "konsep pemasaran adalah suatu falsafah bisnis yang menyatakan bahwa pemuasan kebutuhan konsumen merupakan syarat ekonomi dan sosial bagi kelangsungan hidup prusahaan."

Pada saat ini, restoran fast food merupakan pilihan yang tepat ditengah situasi perekonomian dan perkembangan penduduk Indonesia. Dengan semakin berkembanya prospek yang dijanjikan oleh usaha restoran fast food, maka akan semakin banyak perusahaan-perusahaan baru yang muncul dan bergerak dalam industri yang sama. Sebagaimana tabel di bawah ini memperlihatkan bahwa banyak perusahaan-perusahaan yang terlibat dalam industri fast food di Indonesia yang didirikan dengan system waralaba (franchise), yaitu sebagai berikut:

Tabel 1: Daftar Top 10 Perusahaan Restoran Fast food di Indonesia Tahun 2014

\begin{tabular}{|c|l|l|c|}
\hline No & \multicolumn{1}{|c|}{$\begin{array}{c}\text { Nama } \\
\text { Restoran }\end{array}$} & \multicolumn{1}{|c|}{$\begin{array}{c}\text { Nama } \\
\text { Perusahaan }\end{array}$} & $\begin{array}{c}\text { Jumlah } \\
\text { Gerai }\end{array}$ \\
\hline 1 & $\begin{array}{l}\text { Kentucky } \\
\text { Fried Chicken }\end{array}$ & $\begin{array}{l}\text { Group Gelael/ PT } \\
\text { fast food } \\
\text { Indonesia Tbk }\end{array}$ & 400 \\
\hline 2 & Pizza Hut & $\begin{array}{l}\text { PT Sriboga } \\
\text { Ratujaya }\end{array}$ & 200 \\
\hline 3 & A\&W & Yum! Brands Inc. & 200 \\
\hline 4 & $\begin{array}{l}\text { California } \\
\text { Fried Chicken }\end{array}$ & $\begin{array}{l}\text { PT Pionerindo } \\
\text { Gourmet } \\
\text { Internasional Tbk }\end{array}$ & 183 \\
\hline 5 & $\begin{array}{l}\text { Hoka-Hoka } \\
\text { Bento }\end{array}$ & $\begin{array}{l}\text { Paulus Arifin/ PT } \\
\text { Eka Boganiti }\end{array}$ & 134 \\
\hline 6 & Texas Chiken & $\begin{array}{l}\text { PT Cipta Selera } \\
\text { Murni }\end{array}$ & 133 \\
\hline 7 & mcDonald's & $\begin{array}{l}\text { PT Rekso } \\
\text { Nasional Food }\end{array}$ & 112 \\
\hline 8 & $\begin{array}{l}\text { Papa Ron's } \\
\text { Pizza }\end{array}$ & $\begin{array}{l}\text { PT Setiamandiri } \\
\text { Mitratama Tbk }\end{array}$ & 34 \\
\hline 9 & Burger King & $\begin{array}{l}\text { PT Sari Burger } \\
\text { Idonesia }\end{array}$ & 18 \\
\hline 10 & Izzi Pizza & $\begin{array}{l}\text { PT Sri Agung } \\
\text { Cahaya Sakti }\end{array}$ & $\begin{array}{l}\text { Jhon Lutsi/ PT } \\
\text { Soho Musik }\end{array}$ \\
\hline 11 & $\begin{array}{l}\text { Avenue Pizza } \\
\text { Edisi:XXVI/ }\end{array}$ \\
\hline
\end{tabular}

Sumber: Majalah SWA Edisi: XXVII| 8-12 September 2014 
Berdasarkan tabel di atas, maka dapat diketahui bahwa persaingan yang tarjadi antar restoran cepat saji di Indonesia cukup kompetitif. Data di atas menunjukkan perkembangan tertinggi pada perusahaan restoran fast food di Indonesia peringkat pertama adalah ditempati oleh Kentucy Fried Chicken (KFC) dengan jumlah gerai paling banyak yaitu mencapai 400 gerai, peringkat kedua dimiliki oleh Pizza Hut dan A\&W dengan jumlah gerai masing-masing sebanyak 200 gerai dan disusul pada peringkat ketiga oleh California Fried Chicken dengan jumlah gerai sebanyak 183. Dari beberapa peringkat restoran fast food yang ada, ternyata Mc Donald's hanya mampu berada di posisi ke 6 dengan jumlah gerai sebanyak 112 yang tersebar di seluruh Indonesia. Hal ini menunjukkan tingginya perkembangan pangsa pasar restoran cepat saji yang ada di Indonesia.

Tingkat persaingan tersebut dapat dipengaruhi oleh berbagai faktor yang mempengaruhinya seperti lokasi, pelayanan, kualitas produk, serta faktor lainnya. Sehingga menjadi suatu tuntutan tersendiri bagi setiap perusahaan untuk dapat mempertahankan loyalitas pelanggan agar tetap setia pada merek yang digunakan.

Semakin berkembangnya dunia usaha dan semakin ketatnya persaingan, perusahaan dituntut untuk mampu menciptakan strategi yang tepat dan selalu berorientasi pada selera konsumen tanpa mengabaikan tujuan perusahaan. Tercapainya tujuan tersebut bukankah suatu kebetulan melainkan suatu pemikiran yang matang dan teliti oleh mereka yang bertanggung jawab atas suatu aktivitas pembelian suatu produk. Cepat atau lambat perusahaan harus memperbaiki kemampuannya.

Kiblat perusahaan adalah para pelaggan dan semua fungsi bekerjasama untuk melayani dan memuaskan konsumen, yang mana salah satunya adalah dengan memberikan nilai lebih terhadap produk yang dipasarkan, dengan memberikan layanan yang berkualitas, dimana keberadaan layanan yang berkualitas ini pun secara empiris dan realistis memang terbukti mampu memberikan kontribusi yang optimal dalam meningkatkan keputusan pemebelian oleh konsumen. (Rahma:2007)

Selain faktor kualitas produk, lokasi juga mempengaruhi sesorang dalam mengambil keputusan pembelian. Komponen yang menyangkut lokasi (Tjiptono, 2001) meliputi: pemilihan lokasi yang strategis (mudah dijangkau), di daerah sekitar pusat perbelanjaan, dekat pemukiman penduduk, aman dan nyaman bagi pelanggan, adanya fasilitas yang mendukung, seperti adanya lahan parkir, serta faktor-faktor yang lainnya. Konsumen melakukan beberapa pertimbangan dalam menentukan keputusan pembelian terkait dengan lokasi yang diantaranya adalah dekat dengan sarana pendidikan, dekat dengan kantor dan dekat dengan tempat-tempat umum. Primananda (2010) dalam penelitiannya mendapatkan hasil bahwa variabel lokasi berpengaruh positif dan signifikan terhadap keputusan pembelian.

Menurut Nasution 2004:50 Bila penilaian yang dihasilkan merupakan penilaian yang positif, maka kualitas layanan ini akan berdampak pada terjadinya keputusan pembelian.

Baik buruknya kualitas layanan jasa menjadi tanggung jawab seluruh bagian organisasi perusahaan. Pola konsumsi dangaya hidup pelanggan menuntut perusahaan mampu memberikan pelayanan yang berkualitas. Keberhasilan perusahaan dalam memberikan pelayanan yang berkualitas dapat ditentukan dengan pendekatan service quality yang telah dikembangkan oleh Parasuraman, Berry dan Zenthaml (dalam Ika, 2010).

Menurut Schiffman dan Kanuk (dalam Wijayanti, 2008) secara umum keputusan pembelian adalah seleksi dari dua atau lebih pilihan alternatif.

\section{TINJAUAN PUSTAKA}

Kualitas produk merupakan faktor utama dalam perusahaan. Kualitas produk merupakan kebijakan penting dalam meningkatkan daya saing produk yang harus memberikan kepuasan kepada konsumen yang melebihi atau paling tidak sama dengan kualitas produk dari pesaing. Menurut Crosby 1997(dalam Na'in 2013) 
"kualitas produk adalah produk yang sesuai dengan yang diisyaratkan atau distandartkan. Suatu produk memiliki kualitas apabila sesuai dengan standart kualitas yang telah ditentukan".

Kotler dan Keller (2009:143) menyatakan bahwa kualitas produk atau jasa adalah totalitas fitur dan karakteristik produk atau jasa atau jasa yang bergantung pada kemampuannya untuk memuaskan kebutuhan yang dinyatakan atau tersirat Berdasarkan definisi tentang kualitas, kita boleh menyatakan bahwa pada dasarnya kualitas mengacu kepada pengertian pokok:

1. Kualitas produk atau jasa terdiri dari sejumlah keistimewaan produk atau jasa, baik keistimewaan langsung maupun keistimewaan atraktif yang memenuhi keinginan pelanggan dan dengan demikian memberikan kepuasan atas penggunaan produk atau jasa itu.

2. Kualitas produk atau jasa terdiri dari segala sesuatu yang bebas dari kekurangan atau kerusakan.

Lokasi berpengaruh terhadap dimensi-dimensi pemasaran strategis, seperti fleksibilitas, competitive positioning, manajemen permintaan, dan fokus strategis (Fitzsimmons \& Fitzsimmons, 1994) dalam buku Tjiptono (2006:147).Fleksibilitas suatu lokasi merupakan ukuran sejauh mana sebuah jasa mampu bereaksi terhadap situasi perekonomian yang berubah.Keputusan pemilihan lokasi berkaitan dengan komitmen jangka panjang terhadap aspek-aspek yang sifatnya capital intensif.Oleh karena itu, penyedia jasa harus benar-benar mempertimbangkan, menyeleksi dan memilih lokasi yang responsive terhadap kemungkinan perubahan ekonomi, geografis, budaya, persaingan dan peraturan di masa mendatang.

Pemilihan tempat atau lokasi memerlukan pertimbangan cermat terhadap beberapa faktor berikut. (Tjiptono, 2006:147).

1. Akses, misalnya lokasi yang dilalui atau mudah dijangkau sarana transportasi umum.

2. Visibilitas, yaitu lokasi atau tempat yang dapat dilihat dengan jelas lebih dari jarak pandang normal.
3. Lalu lintas (traffic,) menyangkut dua pertimbangan utama berikut:

a. Banyaknya orang yang lalu-lalang memberikan peluang besar terhadap terjadinya perencanaan, dan/atau tanpa melalui usaha-usaha khusus.

b. Kepadatan dan kemacetan lalu lintas bisa pula menjadi hambatan, misalnya terhadap pelayanan kepolisian, pemadam kebakaran, atau ambulan.

4. Tempat parkir yang luas, nyaman, dan aman baik untuk kendaraan roda dua maupun roda empat.

5. Ekspansi, yaitu tersedia tempat yang cukup luas untuk perluasan usaha dikemudian hari.

6. Lingkungan, yaitu daerah sekitar yang mendukung jasa yang ditawarkan. Contohnya, warung makan berdekatan dengan daerah kos, asrama mahasiswa, kampus, atau perkantoran.

7. Kompetisi, yaitu lokasi pesaing. Sebagai contoh, dalam menentukan lokasi wartel (warung telekomunikasi), perlu dipertimbangkan apakah dijalan atau daerah yang sama terdapat banyak wartel lainnya. Menariknya, dalam sejumlah industri justru ada kecendrungan perusahaan sejenis yang menempati lokasi berdekatan. Contohnya bengkel, showroom mobil, pengecer sepatu dan pakaian, toko mebel, dan seterusnya.

8. Peraturan pemerintah, misalnya ketentuan yang melarang bengkel kendaraan bermotor terlalu berdekatan dengan pemukiman penduduk.

Kualitas mengandung banyak definisi dan makna karena orang yangberbeda akan mengartikannya secara berlainan, seperti kesesuaian denganpersyaratan atau tuntutan, kecocokan untuk pemakaian perbaikan berkelanjutan,bebas dari kerusakan atau cacat, pemenuhan kebutuhan pelanggan, melakukansegala sesuatu yang membahagiakan.

Dalam perspektif TQM (Total QualityManagement) kualitas dipandang secara luas, yaitu tidak hanya aspek hasil yangditekankan, tetapi juga meliputi proses, lingkungan dan manusia.Hal ini jelastampak dalam defenisi yang dirumuskan oleh Goeth dan 
Davis yang dikutipTjiptono (2012:51) bahwa kualitas merupakan suatu kondisi dinamis yangberhubungan dengan produk, jasa, manusia, proses, dan lingkungan yangmemenuhi atau melebihi harapan.Sebaliknya, definisi kualitas yang bervariasi dariyang kontroversional hingga kepada yang lebih strategik.

Menurut Garvin yang dikutip Tjiptono (2012:143) menyatakan bahwaterdapat lima perspektif mengenai kualitas, salah satunya yaitu bahwa kualitasdilihat tergantung pada orang yang menilainya, sehingga produk yang palingmemuaskan preferensi seseorang merupakan produk yang berkualitas palingtinggi. Pelayanan dapat didefinisikan sebagai segala bentuk kegiatan/aktifitas yang diberikan oleh satu pihak atau lebih kepada pihak lain yang memiliki hubungan dengan tujuan untuk dapat memberikan kepuasan kepada pihak kedua yang bersangkutan atas barang dan jasa yang diberikan.

Pada prinsipnya konsep pelayanan memiliki berbagai macam definisi yang berbeda menurut penjelasan para ahli, namun pada intinya tetap merujuk pada konsepsi dasar yang sama. Menurut Sutedja (2007:5) pelayanan atau servis dapat diartikan sebagai sebuah kegiatan atau keuntungan yang dapat ditawarkan oleh satu pihak kepada pihak lain. Pelayanan tersebut meliputi kecepatan melayani, kenyamanan yang diberikan, kemudahan lokasi, harga wajar dan bersaing (Sunarto, 2007:105).Menurut Jusuf Suit dan Almasdi (2012:88) untuk melayani pelanggan secara prima kita diwajibkan untuk memberikan layanan yang pasti handal, cepat serta lengkap dengan tambahan empati dan penampilan menarik.Sedangkan menurut Gronroos (dalam Ratminto, 2005:2) pelayanan adalah suatu aktifitas atau serangkaian aktifitas yang bersifat tidak kasat mata (tidak dapat diraba) yang terjadi sebagai akibat adanya interaksi antara konsumen dengan karyawan atau hal-hal lain yang disediakan oleh perusahaan pemberilayanan yang dimaksudkan untuk memecahkan permasalahan konsumen/pelanggan.

Ciri-ciri pelayanan yang baik menurut Kasmir (2005:39) dirumuskan sebagai berikut:
1. Bertanggung jawab kepada setiap pelanggan/pengunjung sejak awal hingga selesai.

2. Mampu melayani secara cepat dan tepat.

3. Mampu berkomunikas.

4. Mampu memberikan jaminan kerahasiaan setiap transaksi.

5. Memiliki pengetahuan dan kemampuan yang baik.

6. Berusaha memahami kebutuhan pelanggan/pengunjung.

7. Mampu memberikan kepercayaan kepada pelanggan/pengunjung.

Pengertian kualitas jasa atau pelayanan berpusat pada upaya pemenuhan kebutuhan dan keinginan pelanggan serta ketetapan penyampaiannya untuk mengimbangi harapan pelanggan.Menurut Lewis \& Booms (dalam Tjiptono, 2012:157) mendefinisikan kualitas pelayanan secara sederhana, yaitu ukuran seberapa bagus tingkat layanan yang diberikan mampu sesuai dengan ekspektasi pelanggan. Artinya kualitas pelayanan ditentukan oleh kemampuan perusahaan atau lembaga tertentu untuk memenuhi kebutuhan yang sesuai dengan apa yang diharapkan atau diinginkan berdasarkan kebutuhan pelanggan/pengunjung. Dengan kata lain, faktor utama yang mempengaruhi kualitas pelayanan adalah pelayanan yang diharapkan pelanggan/pengunjung dan persepsi masyarakat terhadap pelayanan tersebut. Nilai kualitas pelayanan tergantung pada kemampuan perusahaan dan stafnya dalam memenuhi harapan pelanggan secara konsisten.

Berdasarkan tinjauan pustaka yang telah disajikan tersebut maka disusun hipotesis sebagai berikut;

$\mathrm{H} 1$ : diduga kualitas produk berpengaruh terhadap keputusan pembelian pada McDonald's

H2 : diduga lokasi berpengaruh terhadap keputusan pembelian pada McDonald's

H3 : diduga kualitas layanan berpengaruh terhadap keputusan pembelian pada McDonald's. 


\section{METODE PENELITIAN}

\section{Populasi}

Populasi yang diamati adalah seluruh pelanggan yang pernah makan di Restaurant McDonald's GKB.

\section{Sampel}

Dalam penelitian ini penarikan sampel dilakukan dengan teknik nonprobability sampling, yaitu teknik pengambilan sampel yang tidak memberikan peluang/kesempatan sama bagi setiap unsur (anggota) populasi untuk dipilih menjadi anggota sampel. Metode yang digunakan dalam penelitian ini adalah sampling incidental, yaitu teknik penentuan sampel berdasarkan kebetulan, siapa saja yang kebetulan bertemu dengan peneliti dapat digunakan sebagai sampel apabila orang ditemui tersebut di pandang cocok sebagai sumber data sugiyono, $(2013 ; 124)$.

Penelitian ini mengambil sampel berjumlah 100 orang yang dihitung dengan rumus slovin.

\section{Definisi Operasional}

\section{Variabel Kualitas Produk (X1)}

Kualitas produk adalah menunjukkan ukuran tahan lamanya produk itu, dapat dipercayai produk tersebut, ketepatan (precition) produk, dari segi pandangan pemasaran kualitas diukur dalam ukuran persepsi pembeli tentang mutu atau kualitas produk tersebut. Adapun indikator kualitas produk yaitu :
a. Kualitas produk
b. Ciri atau keistimewaan produk
c. Keragaman ukuran produk.

2. Variabel Lokasi (X2)

Lokasi adalah tempat dimana suatu
perusahaan melakukan kegiatan
operasionalnya. Dari situ disusun indikatorindikator yang terkait dalam penentuan lokasi perumahan. Adapun indikator dari variabel lokasi adalah :
a. Akses lokasi
b.Tempat parkir yang luas dan aman
c. Lingkungan yang mendukung

3. Variabel Kualitas Pelayanan (X3)

kualitas pelayanan adalah suatu kualitas pelayanan yang bergantung pada tiga hal, yaitu system, tehnologi dan manusia pada pelayanan di restaurant McDonald's (Irawan,
2009: 57). Adapun indikator pengukuran variabel kualitas pelayanan adalah:
a. Responsiveness (Ketanggapan)
b. reliability (keandalan)
c. emphaty (empati)
d. assurance (jaminan)
e. tangibles (bukti langsung)

4. Keputusan Pembelian (Y)

Keputusan pembelian konsumen adalah saat dimana seorang pelanggan atau sekelompok pelangganyang mengambil keputusan harus mempunyai satu pilihan dari beberapa alternatif yang ada. Bila seorang dihadapkan pada dua pilihan, yaitu membeli atau tidak membeli dan kemudian dia memilih membeli, maka dia dalam posisi membuat suatu keputusan. Adapun indikator dari variable keputusan pembelian sebagai berikut:
a. Pengenalan masalah
b. Pencarian informasi
c. Evaluasi alternative

Metode Pengumpulan Data Teknik pengambilan data penelitian ini dengan metode angket (kuesioner). Kuesioner yaitu memperoleh data dengan cara mengajukan daftar pertanyaan tertulis secara lengkap tentang masalah yang akan dibahas, tentang kualitas produk, lokasi dan kualitas pelayanan terhadap keputusan pembelian pada restaurant McDonald's GKB.

\section{HASIL DAN PEMBAHASAN \\ Deskripsi Karakteristik Responden}

Responden yang di tentukan sebagai sampel adalah sebanyak 100 orang. Setiap responden di beri lembar kuesioner untuk memberikan jawaban atas pernyataan yang telah di sediakan. Penelitian ini akan mengidentifikasi berdasarkan jenis kelamin, usia dan profesi mengenai responden.

Berikut ini data karekteristik responden yang diperoleh dilapangan: karakteristik responden berdasarkan Jenis Kelamin. Berdasarkan hal tersebut dapat dilihat bahwa sebanyak 42 responden atau jika dipersentasekan sebesar $42 \%$ adalah responden yang berjenis kelamin laki-laki sebanyak 58 responden atau 
jika dipersentasekan sebesar 58\% yang berjenis kelamin perempuan.

Karakteristik responden berdasarkan Usia. Berdasarkan hal tersebut dapat dilihat bahwa sebanyak 24 responden atau jika dipersentasekan sebesar $24 \%$ adalah responden yang berusia 15 20 tahun, sebanyak 23 responden atau jika dipersentasekan sebesar 23\% yang berusia 21-26 tahun, sebanyak 24 responden atau jika dipersentasekan sebesar $24 \%$ adalah responden yang berusia 27-32 tahun, sebanyak 21 responden atau jika dipersentasekan sebesar $21 \%$ yang berusia 33-38 tahun, Sedangkan sebanyak 8 responden atau sebesar $8 \%$ merupakan responden yang berusia 39-44 tahun.

Karakteristik responden berdasarkan profesi, bahwa sebanyak 21 responden atau jika dipersentasekan sebesar $21 \%$ adalah responden berprofesi swasta, sebanyak 18 responden atau jika dipersentasekan sebesar 18\% adalah responden berprofesi wiraswasta, sebanyak 17 responden atau jika dipersentasekan sebesar $17 \%$ responden berprofesi Ibu Rumah Tangga, Sedangkan sebanyak 44 responden atau jika dipersentasekan sebesar $44 \%$ merupakan responden berprofesi pelajar/mahasiswa.

\section{Uji Instrumen}

Berdasarkan hasil uji validitas dapat dijelaskan bahwa nilai validitas Kualitas Produk, Lokasi, Kualitas Pelayanan dan Keputusan dari keseluruhan lebih besar dari 0,196 maka dapat dikatakan bahwa butir-butir pertanyaan itu valid atau memiliki validitas konstruk yang baik. Sedangkan Berdasarkan hasil uji, dapat dijelaskan bahwa nilai Cronbach Alpha > 0,60 yaitu : 0,$829 ; 0,829 ; 0,764$; dan 0,824 , maka konstruk kuisioner Kualitas Produk $\left(\mathrm{X}_{1}\right)$, Lokasi $\left(\mathrm{X}_{2}\right)$, Kualitas Kualitas Pelayanan $\left(\mathrm{X}_{3}\right)$ dan Keputsan Pembelian (Y).

\section{Analisis Uji Asumsi Klasik}

1. Uji Normalitas

Hasil grafik Normal P-P Plot of Regression Standardized Residual menggambarkan penyebaran data disekitar garis diagonal dan penyebarannya mengikuti arah garis diagonal grafik tersebut, maka model regresi yang digunakan dalam penelitian ini memenuhi asumsi normalitas.

2. Uji Multikolineritas

Berdasarkan hasil pengolahan data diperoleh tolerance value kualitas produk, lokasi dan kualitas pelayanan menunjukkan lebih dari 0,10 yaitu $0.876,0.640,0.609$, dan dapat dilihat bahwa semua variabel independen memiliki nilai VIF $<10$ yaitu $1.141,1.563$, 1.642. 1.Dengan demikian maka dapat disimpulkan bahwa tidak terjadi kolerasi di antara variabel-variabel independen yang diuji.

3. Uji Heteroskedastisitas

Hasil menunjukkan bahwa Nilai Uji GlejserKualitas Produk(X1) 0.890, Lokasi (X2) 0.192 dan Kualitas Pelayanan (X3) 0.091, hal tersebut menunjukan tidak terdapat gejala heteroskedastisitas karena hasil sig. > 0.05 .

\section{Analisis Data}

Berdasarkan Analisis Regresi Linear Berganda maka diperoleh persamaan sebagai berikut :

\section{$Y=0,303+0,268 x_{1}+0,319 x_{2}+0,226 x_{3}+e$}

1. Nilai Konstanta (a) sebesar 0.303 artinya jika Kualitas Produk $\left(\mathrm{X}_{1}\right)$, Lokasi $\left(\mathrm{X}_{2}\right)$ dan Kualitas Pelayanan $\left(X_{3}\right)$ bernilai 0 , maka Keputusan Pembelian (Y) nilainya 0.303

2. Jika Variabel Kualitas $\operatorname{Produk}\left(\mathrm{X}_{1}\right)$ berubah dengan satu satuan nilai, maka $\mathrm{Y}$ akan berubah sebesar 0.268 satuan. Dengan anggapan Lokasi $\left(\mathrm{X}_{2}\right)$ dan Kualitas Pelayanan $\left(\mathrm{X}_{3}\right)$ tetap.

3. Jika Lokasi $\left(\mathrm{X}_{2}\right)$ berubah dengan satu satuan nilai, maka $\mathrm{Y}$ akan berubah sebesar 0,319 satuan nilai dengan anggapan Kualitas Produk $\left(\mathrm{X}_{1}\right)$ dan Kualitas Pelayanan $\left(\mathrm{X}_{3}\right)$ tetap.

4. Jika Kualitas Pelayanan $\left(\mathrm{X}_{3}\right)$ berubah dengan satu satuan nilai, maka $\mathrm{Y}$ akan berubah sebesar 0,226 satuan nilai dengan anggapan Kualitas Produk $\left(\mathrm{X}_{1}\right)$ dan Lokasi $\left(\mathrm{X}_{2}\right)$ tetap. 


\section{Koefisien Determinasi $\left(\mathbf{R}^{\mathbf{2}}\right)$}

Hasil Koefisien determinasi $\left(\mathrm{R}^{2}\right)$

Berdasarkan data diatas maka diperoleh nilai Adjusted R Square $=0,544$ dapat dikatakan bahwa perubahan variabel terikat keputusan pembelian (Y) sebesar 54.4\% disebabkan oleh variabel kualitas produk $\left(\mathrm{X}_{1}\right)$, lokasi $\left(\mathrm{X}_{2}\right)$ dan kualitas pelayanan $\left(\mathrm{X}_{3}\right)$ sedangkan selebihnya dapat dijelaskan oleh faktor-faktor lain diluar variabel tersebut.

1. Berdasarkan data diatas maka diperoleh nilai $\mathrm{R}$ Square $=0,558$ artinya bahwa perubahan dalam variabel terikat keputusan pembelian (Y) dapat dijelaskan oleh perubahanperubahan dalam variabel kualitas produk $\left(\mathrm{X}_{1}\right)$, lokasi $\left(\mathrm{X}_{2}\right)$ dan kualitas pelayanan $\left(\mathrm{X}_{3}\right)$ sebesar $55.8 \%$ sedangkan selebihnya dapat dijelaskan oleh faktor-faktor lain diluar variabel tersebut.

2. $\mathrm{R}=0,747$ artinya kuatnya hubungan antar variabel independen (X) bersama-sama terhadap variabel (Y) yaitu 74,7\%.

\section{Analisis Uji hipotesis}

Hasil penelitian terhadap variabel Kualitas Produk $\left(\mathrm{X}_{1}\right)$ diperoleh nilai $\mathrm{t}_{\text {hitung }}$ sebesar 4,022, sedangkan $\mathrm{t}$ tabel sebesar 1,985. Hasil ini menunjukan bahwa $\mathrm{t}$ hitung $>\mathrm{t}$ tebel dengan signifikan sebesar 5\%. Dengan demikian hasil perhitungan statistik menunjukan bahwa secara parsial variabel Kualitas Produk $\left(\mathrm{X}_{1}\right)$ terbukti berpengaruh signifikan terhadap Keputusan Pembelian Pada Restaurant McDonald's GKB.

Hasil penelitian terhadap variabel Lokasi $\left(\mathrm{X}_{2}\right)$ diperoleh nilai t hitung sebesar 3,970, sedangkan $\mathrm{t}$ tabel sebesar 1,985. Hasil ini menunjukan bahwa $t$ hitung $>\mathrm{t}$ tebel dengan signifikan sebesar $5 \%$. Dengan demikian hasil perhitungan statistik menunjukan bahwa secara parsial variabel Lokasi $\left(\mathrm{X}_{2}\right)$ terbukti berpengaruh signifikan terhadap Keputusan Pembelian Pada Restaurant McDonald's GKB.

Hasil penelitian terhadap variabel Kualitas Pelayanan $\left(\mathrm{X}_{3}\right)$ diperoleh nilai $\mathrm{t}$ hitung sebesar
3,785, sedangkan t tabel sebesar 1,985. Hasil ini menunjukan bahwa $t$ hitung $>t$ tebel dengan signifikan sebesar 5\%. Dengan demikian hasil perhitungan statistik menunjukan bahwa secara parsial variabel Kualitas Pelayanan $\left(\mathrm{X}_{3}\right)$ terbukti berpengaruh signifikan terhadap Keputusan Pembelian Pada Restaurant McDonald's GKB.

\section{SIMPULAN}

Berdasarkan hasil analisis data dan interprestasi hasil maka kesimpulan yang diambil dari penelitian dengan judul "Pengaruh kualitas produk, Lokasi dan kualitas Pelayanan Terhadap Keputusan Pembelian Pada Restaurant McDonald's GKB." adalah sebagai berikut:

1. Kualitas Produk mempunyai pengaruh signifikan secara persial terhadap Keputusan Pembelian pada Restaurant McDonald's GKB.

2. Lokasi mempunyai pengaruh signfikan secara persial terhadap Keputusan Pembelian Pada Restaurant McDonald's GKB.

3. Kualitas Pelayanan mempunyai pengaruh signifikan secara parsial terhadap Keputusan Pembelian pada Restaurant McDonald's GKB.

Berdasarkan hasil analisis, pembahasan, dan kesimpulan penelitian, maka rekomendasi dari peneliti dapat diberikan sebagai berikut :

\section{Bagi Aspek Manajerial}

1. Melihat koefisien terbesar variabel kualitas produk memiliki nilai tetinggi pada item Produk restoran McDonald's memiliki keistimewaan produk, maka dari itu perusahaan sebaiknya tetap mempertahankan dan terus meningkatkan keistimewaan produk tersebut.

2. Melihat koefisien terbesar variabel Lokasi memiliki nilai tetinggi pada item Tempat Lokasi restoran McDonald's bahwa tempat parkir luas dan aman, dapat menjadi pilihan yang memadai bagi konsumen,

3. Melihat koefisien variabel kualitas pelayanan memiliki nilai tertinggi pada item bahwa restoran McDonald's penampilan para pegawai terlihat rapi dan bersih dalam 
berseragam sehingga menarik perharhatian pelanggan.

\section{Bagi peneliti selanjutnya}

Bagi peneliti selanjutnya hasil penelitian ini dapat digunakan sebagai referensi, bagi peneliti selanjutnya dengan memperbanyak jumlah variabel-variabelnya seperti promosi, iklan ataupun citra merk dan menggunakan teknik analisis yang berbeda.

\section{DAFTAR PUSTAKA}

Baum, Feigen A.V. 2001. Kendali Mutu Terpadu. (Alih Bahasa : Hudayana Kandah Jaya) Edisi Ketiga, Jakarta : Erlangga.

Fandy, Tjiptono, 2006. Manajemen Jasa. Edisi Kedua. Yogyakarta: Andi Offset.

Fandy Tjiptono, 2008. Strategi Pemasaran: Edisi 3. Yogyakarta

Garvin, D.A. 2000. Kualitas Produk : Alat Strategi Yang Penting . Jakarta. Free Press. Edisi III.

Ghozali, Imam, 2005, Analisis Multivariate dengan Program SPSS, Badan Penerbit Universitas Diponegoro Semarang.

Ghozali, Imam, 2013. Aplikasi Analisis Multivariate Dengan Program SPSS, Edisi Tujuh, BP Universitas Diponegoro, Semarang.

Kotler, Philip and Kevin L. Keller. 2008, Manajemen pemsaran, edisi 13 jilid 1, Penerbit Erlangga, PT Gelora Aksara Pratama. 2009. Manajemen Pemasaran Jilid 1, edisi ketigabelas, Terjemahan Bob Sabran, MM. Jakarta: Penerbit Erlangga.

2009. Manajemen Pemasaran Jilid 2, edisi ketigabelas, Terjemahan Bob Sabran, MM. Jakarta: Penerbit Erlangga

Kotler, Philip dan Gary Armstrong, 2001, Prinsip-prinsip Pemasaran, Jilid 1, Edisi Kedelapan, Jakarta, Erlangga.

........, 2001, Prinsip-prinsip Pemasaran, Jilid 2, Edisi Kedelapan, Jakarta, Erlangga.

Kotler, Philip; Armstrong, Garry, 2008. Prinsipprinsip Pemasaran, Jilid 1, Erlangga, Jakarta.
Lasander 2013 Citra Merek, Kualitas Produk, Dan Promosi Pengaruhnya Terhadap Kepuasan Konsumen Pada Makanan Tradisional. Vol 1, No 3.

Lupiyoadi, R. dan Hamdani, A. 2009. Manajemen Pemasaran Jasa. Jakarta: Salemba Empat.

Majalah SWA Edisi: XXVII| 8-12 September 2014 : http://swa.co.id/digitalmagazine, [diakses 21 September 2016].

Oentoro, Deliyanti, 2012, Manajemen Pemasaran Moderen, Laks Bang Pressindo, Yogyakarta.

Rokim, Muh. Abdul, Lubis, Nawazirul \& Wijayanto, Andi 2013, Pengaruh Harga, Bauran Produk, Dan Kualitas Pelayanan Terhadap Keputusan Pembelian Di Pasaraya Sri Ratu Semarang, Journal Of Social And Politic Diponegoro.

Saleh, Akh Muwafik. (2010). Public Service Communication. Malang : UMM Press.

Sugiyono, 2008, Metode Penelitian pendidikan, CV Alfabeta, Bandung. 2010 Metode Penelitian Bisnis, CV Alfabeta Bandung.

Sugiyono, 2013. Statistika Untuk Penelitian. CV Alfabeta Bandung.

Sutisna, 2003, Perilaku Konsumen \& Komunikasi Pemasaran, Remaja Rosdakarya, bandung

Tjiptono, 2008, Strategi Pemasaran, Edisi , ANDI: Yogyakarta.

Tjiptono, Fandy dan Gregorius Chandra, 2012. Pemasaran Strstegik. Yogyakarta, ANDI.

Utami Widya, Christina. 2012, Manajemen Ritel, Edisi 2. Jakarta : Salemba Empat

Widagdo, Herry.2011 Analisis Pengaruh Kualitas Layanan dan Promosi terhadap Keputusan Konsumen Membeli Komputer. Vol.1. No.1.

Wijayanti, Irine Diana Sari. 2008, Manajemen, Yogyakarta: Mitra Cendikia Press. http://www.mcdonalds.co.id/tentangmcdonalds/info-perusahaan/sejarahmcdonalds diakses 02 Mei 2017 